\title{
THE DEFENDERS OF FAITH. THE CORRESPONDENCE BETWEEN FERENC BALOGH, FATHER OF THE NEW ORTHODOXY MOVEMENT, AND EDUARD BÖHL, REFORMED PIETIST PROFESSOR OF DOGMATICS FROM VIENNA
}

\author{
TEOFIL KOVÁCS*
}

Budapest Metropolitan University

\begin{abstract}
The present study examines how two famous professors in Central Europe decided to network together in order to promote traditional Christian faith through New Orthodoxy of Debrecen and Reformed Pietist of Vienna which became the source of renewal in the Reformed Church of Hungary. Their correspondence bears a witness to the endeavour to train, teach and guide young students enabling them to become persons of influence in the church. This research paper examines contents of the exchange of letters between Ferenc Balogh of Debrecen and Eduard Böhl from Vienna with a particular view on how they educated the future generation along the evangelical-pietist faith that both professors adhered to.
\end{abstract}

KEYWORDS: Revival, New Orthodox, Eduard Böhl, Ferenc Balogh, Reformed Pietism

\section{Promoting Revivalist through Education and Teaching}

In this study I wish to examine the way in which two internationally renowned professors standing on the ground of traditional faith built an intellectual network in the Austro-Hungarian Monarchy, a network which could not only withstand the intellectual challenges of the era, but also became a source of renewal in the Church. One important link in this process was the education and mentoring of the students whom their teachers kept track of after their university studies. Through the system of international peregrination, the professors advisedly tutored new generations. The primary resource of the study was the correspondence of Eduard Böhl, Professor of Systematic Theology in Vienna, and Ferenc Balogh, Professor of Church History and Dogmatics in Debrecen, between 1867 and 1903. A secondary resource it examines are the works about the history of peregrination and of the Church

* TEOFIL KOVÁCS (PhD 2005, University of Debrecen) is an Associate Professor at Budapest Metropolitan University and Vice Director of Manuscript Collection at Debrecen Reformed College, Hungary. Email: teofilk@hotmail.com. 
(Heil 2016: 233-255) from the following aspects: What was the character of the intellectual relationship between Hungary and Western Europe? What was the role of the two professors and of Vienna in the choice of later studies? How did the relationship between Balogh and Böhl start? What was the students' and ministers' language proficiency like? How did Balogh and Böhl attempt to support their students? What happened to the students after their studies? How does the dogmatics of Böhl appear in the letters? How does journalism as a shaping agent of public opinion appear in the letters? Why did Böhl send students to Debrecen? [Böhl's letters to Balogh can be found in the manuscript archives of the Library of the Transtibiscan Reformed Church District under the references TtREK R 1516/24, R 1595/15-16, R 2451, R 2456. Balogh's letters to Böhl are preserved in Amsterdam in the Historisch Documentatiecentrum Vrije Universiteit Amsterdam. https://www.hdc.vu.nl/nl/Images/-108_Eduard_Boehl_tcm215-773569.pdf, (downloaded on 31 August 2017, 108/45 (henceforth = HDC)] [A series of studies has been published recently on the international peregrination of Hungarian students (Magyarországi diákok egyetemjárása az újkorban) edited by László Szögi. Three volumes concern Vienna in the covered era: Szögi L, Kiss JM (2003) Magyarországi diákok bécsi egyetemeken és föiskolákon 1849-1867. Budapest: Eötvös Loránd Tudományegyetem Levéltára (henceforth = Szögi 2003); Patyi G, Simon Z, Szabó M, Szögi L, Varga J (2015) Magyarországi diákok bécsi egyetemeken és föiskolákon 1867-1890. Budapest: Eötvös Loránd Tudományegyetem Levéltára (henceforth = Patyi 2015); Patyi G (2004) Magyarországi diákok bécsi egyetemeken és föiskolákon 1890-1918. Budapest: Eötvös Loránd Tudományegyetem Levéltára] [For the biography of Eduard Böhl, I used Debreceni Protestáns Lap and Karl W. Schwarz's study Zur »entschiedene[n] Wahrung des reformierten Criteriums". Eine fakultätsgeschichtliche Annäherung an den Systematiker Eduard Böhl. In Heil U, Schellenberg A, ed (2016) Frömmigkeit. Historische, systematische, praktische Perspektiven. Wiener Jahrbuch für Theologie 11. V\&R Unipress, Vienna University Press, pp 233255 (henceforth = Schwarz 2016.) Forster TRV (2009) Eduard Böhl's (18361903) Concept for a Re-emergence of Reformation Thought, Frankfurt am Main, Peter Lang.]

This research topic, peregrination, is not without precedent. The intellectual relationship between Hungary and Western Europe was facilitated by the Hungarian system called peregrinatio academica, namely Hungarian students visiting Western European universities centuries before the age of Reformation. Given that in Hungary there was no permanently existing university before 1635, it was the natural way of further studies. As the university founded in 1635 was Catholic, Protestant students kept visiting Western European universities. 
This, however, did not mean that Protestants did not run colleges for higher education, but university qualifications could only be acquired abroad. The tradition of international peregrination thus continued despite the obstacles which the government of the Habsburg Empire applied for religious, political and financial reasons.

As a result of the Karlsbad Resolutions (1819), authorities attempted to interrupt this process (Kovács 2017: 153). This circumstance efficiently facilitated the foundation of the Protestant Theological Institute of Vienna (Szász 2017: 175-187) in 1821, maintained by both the Lutheran and the Reformed Churches, and promoted by those who urged the union of the two devotions. Eduard Böhl became the first Reformed Professor of Dogmatics in this institute.

\section{Theological Background of the Era}

In the middle of the nineteenth century both confessionary Christianity and liberal theology played important roles in reformed theology. Both were present inside the Habsburg Empire. In Hungary both schools emphasised the service of the Church, although from different aspects. The former school was oriented in Pest, while the latter in Debrecen (Kovács 2017: 154). By the late 1860s the so-called 'new orthodoxy of Debrecen] appeared, which may be linked first to Imre Révész Sr. (Zoványi 1977: 506-507) local minister, then to Ferenc Balogh, Professor of Church History (Kovács 2010: 41; Zoványi 1977: 42; Barcza 1988: 570). The Debrecen stream opposed modern religious studies which disavowed the divinity of Christ, rejected corporal resurrection, treated the Virgin Birth as a fairy tale, regarded man as substantially good, and could not cope with Christ's salvation. [Imre Révész (1826-1881) also studied in Vienna in 1851 and 1852. In 1859 he became a correspondent member of the Hungarian Academy of Sciences (MTA) and in 1871 an honorary doctor of the theological faculty in Vienna. Zoványi, Jenő (1977) Egyháztörténeti lexikon. Budapest: MREZS Sajtóosztálya, pp 506-507. (henceforth = Zoványi); Patyi does not mention the Viennese studies of Imre Révész. However, a certain Révész Friedrich enrolled from Újfehértó, likewise, on 6 October 1851. In the register there is 'Emerich' and not 'Friedrich', according to the institute.]

At the same time, German reformed pietism appeared in Vienna, which was also conservative theologically, as it insisted on dogmas and creeds. In the Protestant Theological Institute of Vienna, which mainly educated Czech and Austrian ministers, the confessionary stream was represented by Eduard Böhl, who was the representative professor of the western theological movement, namely reformed confessionary pietism in the markedly liberal theological institution of Vienna (Schwarz 2019: 181-194). 


\section{Eduard Böhl, the Protestant Defender of Faith in Vienna (Hamburg, 1836-Vienna, 1903)}

Eduard Böhl was born in Hamburg, into a wealthy Lutheran-Catholic family. He began his studies in humanities and theology at the University of Berlin, then later he studied in Halle and Erlangen, where he earned a Doctorate in Arts. Later he received the degree of Theological Licentiate at the University of Basel in 1860 and turned to Calvinism in that period. He was appointed professor at the Department of Reformed Dogmatic at the Viennese Protestant Theology Institute on 12 January 1864, then in 1865 he was promoted Doctor of Theology. His inauguration speech was about the Second Helvetic Confession, the knowledge of which he held as the primary duty of his students.

Besides dogmatics, he also taught symbolics, religious philosophy, biblical theology, apologetics, education and New Testament exegetics (DPL 1903: 94-95). He edited the church newspaper titled Evangelische Sonntagsbote aus Österreich between 1865 and 1867 (Geppert 2008: 5), and published in German, Dutch, and English newspapers as well (DPL 1903: 124). He deeply influenced students in Vienna not only from the Monarchy, but also those from Switzerland and Holland. There were students who converted from Judaism to Christianity or from Lutheran to Reformed, causing, however, great scandals. Böhl never preached from a church pulpit. Throughout all his activities he categorically opposed unionist intentions and liberal theology, insulating his position in the Protestant Theological Institution of Vienna (Schwarz 2019: 234).

There were also opportunities for students to meet their professor after the lessons. Böhl himself recorded that he invited ten young men to his home with whom he talked about several topics. [R 1516/24: 17 February 1887] Gatherings and meetings of this kind organised by a professor were common at the university. On such occasions, he paid special attention to his students' later life, but also supported them financially (DPL 1903: 141). He sent some of his students to Elberfeld, to the congregation founded by his father-in-law, Hermann Kohlbrügge, so that they could acquire experience. Kohlbrügge had German and Dutch roots, and he was an outstanding figure of nineteenth century reformed pietism. His congregation served as an example for many. Böhl sent other students to Basel, Amsterdam and Utrecht with letters of recommendations (DPL 1903: 157).

He kept in touch with them later via letters and personal meetings. Until his death he actively organised the Kohlbrügge-group (Schwarz 2019: 184), and its members wrote Böhl reports to him. These were circulated reports on church and school life twice a year, on 5 March, the anniversary of Kohlbrügge's death, and on 15 August, on his birthday. Since the members of this group were from several different countries, Kohlbrügge's impact 
appeared not only in several European countries, but also in Northern America. [Hermann Friedrich Kohlbrügge (1803-1875) was the pastor of the Elberfeld Dutch congregation and a theologist. Barth K (1952) Die protestantische Theologie im 19. Jahrhundert. Zollikon-Zürich: Evangelischer Verlag, 579-587; Stiasny T (1935) Die Theologie Kohlbrügges. Eine gemeinverständliche Darstellung der Lehre P. Dr. Kohbrügges. Düsseldorf; de Reuver A (2004) De drie stukken in de theologie van Luther, Calvijn en Kohlbrugge. Heerenveen; de Reuver A (2005) H. F. Kohlbrugge. Een inleiding met kernteksten. Kampen.]

The influence of Kohlbrügge's theology also spread to Hungary. The members of the corresponding group attempted to spread Calvinist orthodoxy in journals, studies published in books and translations. Preliminarily, I only mention a few, most renowned, names. Károly Rácz (Zoványi 1977: 495; Csohány 1987: 162-164; Szögi 2003: 275), minister of Szapáryfalva, the editor of the periodical Szabad Egyház (Free Church), was first among the Hungarian correspondents. He studied in Vienna, but also visited Kohlbrügge in Elberfeld. He published and distributed Kohlbrügge's sermons in booklets titled Mennyei Lépcső (Stairway to Heaven). Böhl paid special attention to another illustrious correspondent. He would have liked to promote Sándor Venetianer, (Zoványi 1977: 683-684) who was of Jewish origin, into a professor's position. József Erdős (Zoványi 1977: 179-180; Patyi 2015: 590; Csohány 2011: 68-76), later professor in Debrecen, and Zsigmond Keck (Patyi 2015: 592), later minister in Újbánovce and Cservenka, also studied with Böhl in Vienna. József Erdős served in Elberfeld is 1879 as associate minister, but by that time Kohlbrügge had already died. In his later years, as minister in Pancsova, he started to build a church, for which he received significant financial help from the other correspondents. Ferenc Balogh also followed the activity of the group, being the mentor of the above-mentioned students. I am going to write in more detail about Venetianer and Erdős. [Károly Rácz went to secondary school in Debrecen. He enrolled in Vienna on 6 October 1866 and left on 28 July 1867; there was no theological education in Elberfeld. Kósa, L (2001) Az elberfeld-debreceni diákcsere. A magyar református egyház és a német hitvalló egyház kapcsolatának egy fejezete. Protestáns Szemle 2-3: 104-142] [Szabad Egyház (Free Church), bimonthly reformed confessionalist periodical of very miscellaneous content, started by Károly Rácz in 1884, published until 1915.] [Venetianer Sándor, born in Fadd, studied at the faculty of philosphy at the University of Vienna between 1871 and 1872. He enrolled to the Protestant Theological Institute of Vienna on 3 October 1871, from where he left on 13 April 1874, Patyi 2015: 141, 588; then Venetianer studied at the University of Basel between 27 April 1874 and 22 March 1875, Szögi 2000: 50; Schwarz KW (2016) Alexander Venetianer (1853-1902) Ein judenchristlicher Theologe aus dem pannonischen Raum. Historia Ecclesiastica 7(2). Balogh recorded that because of his chaplain's examination Venetianer spent two weeks 
in Debrecen. Balogh helped him with his business, introduced him to other people, but also communicated with Böhl about him. Eventually Balogh recommended him to his friend, Sándor Harsányi in Túrkeve. The Debrecen Diary of Ferenc Balogh, 20 May 1877] [Zsigmond Keck, pastor in Újsóvé, Kórógy, Újbánovce, and Cservenka, founder of the poorhouse in Újbánovce (1861-1944), available online on http://www.macse.org/gudenus/mcsat/fam.aspx?-id=95663; Zsigmond Keck studied in Vienna between 5 October 1880 and 16 August 1883. Patyi 2015: 592]

\section{Ferenc Balogh, the Leader of New Orthodoxy in Debrecen and His Correspondence with Böhl}

As I have previously mentioned, in questions of faith, Böhl took the same theological side as Balogh. Their friendship was formed based on the similarities of their ideas. Böhl's correspondent from Debrecen, Ferenc Balogh studied theology in Debrecen, where he later became professor of church history in 1866. (DPL 1903: 643) As a young student, following the encouragement of József Lugossy (Zoványi 1977: 380), professor of linguistics in Debrecen, he learnt French, German, and English for years (Ötvös 1997: 118).

Between 1863 and 1865 he received scholarships to Paris, London and Edinburgh. He visited England and Scotland on his principal's request. 'In effect, his visit started the real, influential Hungarian peregrination to Scotland' (Kovács 2014: 58). From this time on he had strong relationship with Scottish churchmen. What makes his peregrination interesting is that he did not attend the usual Swiss, Dutch or German universities, but rather Paris, where he experienced both confessional Christianity and liberal theology (Kovács 2010: 49). Besides his numerous academic works, he frequently published both in Hungarian and renowned international Church and academic periodicals (DPL 1913: 643). His main profile was apologetics, which considered confessions as Christian testimonies.

Böhl and Balogh represented the same theological trend, which focused on a return to the confessions. The correspondence between the two professors is kept in Debrecen and Amsterdam. Böhl's 44 letters written to Ferenc Balogh between 1867 and 1897 can be found in the Manuscript Collection of the Library of the Transtibiscan Church District, along with a letter of recommendation by the Viennese professor to Bishop Bálint Révész in favour of his disciple, Zsigmond Keck, dated from 17 July 1883 (Kovács 2017: 159). The collection of the 27 letters addressed to Böhl between 1867 and 1903 are not in Vienna, as one might expect, but since 1980 at the Vrije Universiteit in Amsterdam because Böhl's second wife, Jacqueline van Verschuer (18461921) was of Dutch origin (Schwarz 2019: 243). The material was organised by Kerstin Geppert in 2008. The correspondence is bilingual with the first two letters by the Viennese professor written in French, while later ones in 
German. Böhl was first mentioned in Ferenc Balogh's diary on 19 February 1867, when he wrote that his inaugural speech was published in Böhl's journal, the Evangelische Sonntagsbote. Balogh thought that the translator of the text was Károly Rácz, a Hungarian student studying in Vienna (Debrecen Diary of Ferenc Balogh, 19 February 1868). He noted about the fellow professor: 'He is orthodox, and I respect him. As desolate irreligiousness and faithlessness are diffusing around here, we must return to the Biblical grounds from extreme rationalism.' [Kovács Á, Hörcsik R (2014) A debreceni diákok egyetemjárása Skóciában. Confessio 2014(1): 58; The scholarship of the Free Church of Scotland in Edinburgh was founded in 1863. Hungary and Bohemia each had two positions. The scholarship's conditions expected students to have a decent language proficiency, they had to arrive as early as May or June, as they had to develop their English before the Autumn term which began in November. They were also expected to be honest, virtuous and devoted Christians, ibid. 64-66.]

It was Böhl who initiated the relationship with his letter written on 18 February 1867, which is also recorded in Balogh's diary entry on 26 February 1867 (Debrecen Diary, 26 February 1868). Böhl also noted that he studied the history of Hungarian Church history and would be happy to publish Balogh's papers in his journal, either in French or English, which could be translated. Balogh did not undertake it, but wished to correspond with his Viennese colleague, who offered him an opportunity to write his letters in French. Balogh accepted the offer and did write all his letters in French. Balogh himself shed light on the explanation when he wrote about his language proficiency: 'My education was unique. The French and English languages fell to my lot, and even these at a rather mature age, while German is my weakness. I have difficulties reading in this language... However, I can easily understand the other two one after the other. I have pleasure reading German authors in French or in English. Between 1850 and 1858, when I proceeded with my studies, fear from Austria and the oppressor's language prevailed in the Hungarian environment' (HDC 1886: 30).

Both professors used the language that they each knew best for their correspondence. In Böhl's case it was German, while in Balogh's case it was French, the language better acquired. They also met personally, as Balogh visited his colleague in Vienna. In August 1874, Balogh recorded his not finding Böhl at home (Debrecen Diary, 24 August 1874). In 1877, on his way to Edinburgh, Balogh stayed with Böhl as a guest in Vienna (Debrecen Diary, 2 July 1877). It is apparent that they kept in touch in different forms.

\section{Social and Spiritual Sensitivity of the Two Professors}

The spiritual sensibility of the two professors was very similar. Böhl showed his social sensitivity already with his first student, Károly Rácz, who received 
free boarding after Böhl's personal assistance. We can also see later that Böhl promised Balogh that his protégée, Erdős, was also going to receive free boarding. [R 1516/24: 11 June 1877] In other cases, when inviting Hungarian students, he offered his help in getting support for the genuinely poor ones. [R 1595/15: 29 October 1892] Sensitivity to personal problems also appeared by Balogh too, who wrote: 'Takács's mother visited me, crying, because her younger son, who studies law here, got a pulmonary disease, and according to the doctor's opinion, he has to give up his studies. Her mother took him home to nurse him, as his life is in danger' (HDC 1887).

His remark shows his serious concerns with the life of his students. Like Böhl, Balogh took an interest in his disciples' problems. For example, Böhl asked Balogh to recommend József Póth (Patyi 2015: 593) to his colleagues' attention, so that the student could be granted the allowances of the Debrecen College because of his poverty. [R 1516/24: 7 September 1886] The fact that Balogh acted warm-heartedly, moved Böhl, who asked him to encourage the student to go on with his studies. [József Póth was born in 1865. From 1891 he served in Újverbász, from 1893 in Újbanovce as missionary associate pastor. In 1894 he was elected pastor by the congregation of Német-gyönk. He was consecrated in 1895. From around 1905 he served in Újsóve. Kránitz Z, ed (2003) 'A késő idők emlékezetében éljenek...' A Dunántúli Református Egyházkerület lelkészi önéletrajzai, 1943. A Pápai Református Gyüjtemények Kiadványai, Forrásközlések 13. Jubileumi kötetek 2. Pápa, 853; Patyi 2015: 593 (2 October 1884-11 July 1885)]

The Viennese professor did not only look out for the physical needs of students, but he also considered the education of loyal and faithful ministers primary, as well as the creation of a unity among them, for which he regarded both their practical and theoretical training essential. So, he deliberately introduced his student to clerics who shaped the intellect and the spirituality of their audience. For instance, Károly Rácz travelled from Vienna to Elberfeld in August 1867, where he spent fifteen days with Hermann Friedrich Kohlbrügge, the well-known theologian. This visit made such a great impact on Rácz, that he translated and published Kohlbrügge's short catechism (Szinnyei 1906: 315-318). Among the already mentioned disciples Rácz, Sándor Venetianer, and Zsigmond Keck belonged to the Hungarian Kohlbrüggecircle, which also included the previously mentioned József Erdős, who spent half a year in Elberfeld (Szabad 1884: 4). The professors kept track of their disciples' career after their graduation, also. Böhl commemorated the death of Mihály Deák, his faithful disciple, testifying that such deaths mean great losses for the whole Church. Böhl had taught Deák for two years, after Deák had first studied engineering in Vienna. [R 1516/24: 31 July 1876] We do not know why he changed from engineering to theology, but Böhl's personal fame might have influenced his choice. It is plausible that he followed Böhl's 
suggestion when he went to Utrecht twice. First, he enrolled as a scholarship student of the Stipendium Bernardinum (Zoványi 1977: 71) on 23 September 1872, then in 1873/1874 (Bozzay: 171). [Mihály Deák was born in 1850, in Alvinc. He enrolled for the winter semester of 1870 at the technical university in Vienna. Then he went to the Protestant Theological Institute in Vienna from 10 May 1871 to 27 July 1872, even though Böhl wrote that it was about two years. Patyi 2015: 395, 586.]

His sensitiveness to personal lives can be seen in the case when Böhl wrote that Erdős practiced practical theology beside the deathbed of his father during this period, and the behaviour of the student appealed to him. Erdős learnt a lot, he maintained, and he would get on in his life if he goes on like this. He acted ingeniously and affectionately towards young and old as well. Böhl hoped that the student would obtain Balogh's consent to go to Elberfeld, where he had been invited. [R 245131 July 1879] Balogh also kept in touch with Erdős, from whom he received letters now and then, but he complained that he could not always write to him. 'It is crucial that young men like Erdős get support from those who love them and follow their career with interest. I hope that in the future I will answer your letters more often and faster.' He also expressed his hope that in the future he would be able to keep in touch with him better than before. He also remarked that he was glad to hear about his visit to Elberfeld, hoping that he will profit from the pious congregation there. Balogh was very happy that Erdős had won Böhl's appeal. In connection with him he wrote: 'We both strongly wish that you became a humble but efficient worker of God's country in the bosom of the Hungarian Reformed Church, which greatly needs serious Christian souls.' [HDC: 7 August 1879] Balogh even mentioned the proceedings of Erdős in his rector's report, mentioning that his offices in the College had predicted them (Zoványi 1977: 179). Both professors followed Erdős's career after he went to Pancsova. [R 1516/24: 26 April 1883] When in 1884 Erdős entered a new service, Böhl inquired from Balogh whether Erdős is satisfied with Újsóve. [R 1516/24: 19 November 1884. After his time in Elberfeld, Erdős served as a chaplain in Debrecen from February 1880, then from July 1881 as pastor in Pancsova, from 1884 in Újsóve. Zoványi, 179-180] The professor from Debrecen could report that Erdős works faithfully, and he has credit with his friend in Debrecen. [HDC: 30 March 1885] In a letter to Balogh on 16 May 1888, Böhl sent his regards to Erdős who was going to visit him soon. Böhl at the same time asked Balogh to comfort Venetianer [R 1516/24: 16 May 1888], most probably because instead of Venetianer, Erdős was offered the professorship in Debrecen. This topic will be elaborated on later. [The scholarship was founded in 1761 for the reformed students studying at the University of Utrecht. Originally it was offered to twelve people at 350 Dutch 
guldens for five years, but later the conditions changed. Every year 18 to 20 students received the scholarship, of which 3 or 4 were Hungarians.]

Böhl was especially glad to welcome the already mentioned József Póth and János Kovács, who arrived from Debrecen for the winter semester of 1884. He found the latter especially ambitious and intellectually agile. [R 1516/24: 19 November 1884] Kovács visited Balogh several times, but the professor did not find a position suitable for his talent. As a result, he expected the student to visit Vienna again to find a better opportunity, for which he asked Böhl for support. [R 1516/24: 27 December 1885] Kovács could eventually return to Vienna. A letter dated from June 1886 noted that the student was very sad to leave Vienna. [R 1516/24: 7 June 1886] The fact that five year later, in January 1891 Böhl reported that Kovács visited him, also refers to a functioning social network. Then Böhl warned Kovács to be highly reserved and obedient towards his professors. Böhl asked Balogh not to lose sight of Kovács. Kovács offered to translate studies for Böhl. Böhl asked Balogh whether Kovács was capable of translating, as he could translate his dogmatics. Böhl, however, agreed with Erdős's last letter, who, accordingly, also favoured Kovács, that they must not let him fail, as also his wife was a devout person, and being poor must be a condemnable circumstance only in Hungary. He thought that they must stand up for Kovács for as long

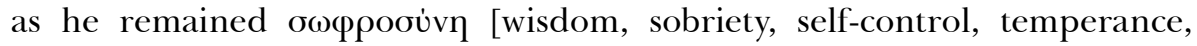
modesty, discretion, prudence], or prudent. Nonetheless he strongly dislikes the Baptists and passionately loves and defends his own church. [R 1516/24: 24 January 1891] It is rather interesting to contrast this statement with Balogh's remark who knew about Kovács' connection to the Baptist. [HDC: 16 February 1891] In a letter of 31 December 1891, Balogh wrote that he had most heartily suggested to Kovács that he apply for the offered American position of a local church, which he had in fact already accepted. The young minister had also sent his professor two letters. [HDC: 31 December 1891] Böhl was pleased to hear that Balogh was keeping an eye on Kovács in America (Puskás 2015: 169-170). [R 1595/15: 29 October 1892, see also: Puskás J, Kovács Á (2017) Amerikai magyar református lelkészek életútja adattári rendszerben 1891-2000. Debrecen: Debreceni Egyetemi Kiadó]

Böhl was also pleased with Gyula Dávid, (Patyi 2015: 593) the former secondary school student from Debrecen, who enrolled to the Vienna institute. He also obtained a scholarship for him to Utrecht. [R 1516/24: 7 June 1886] Balogh wrote: 'He is going to be the pillar of our profession; this is my precious hope.' [HDC: 30 December 1886] 'I can see the changes that went on in him, triggered by your inciting fire, this is 'opus operans'. [HDC: after 30 December 1886] After over a year Böhl inquired again what happened to the student József Póth, whom he asked to write and asked Balogh to remind Póth. [R 1516/24: 18 February 1888] It is apparent that interest in students 
was not limited to only a few of them, as in the correspondence the professors mention sixteen of the 48 Reformed Protestant, two Jewish and one Catholic student who enrolled between 1866 and 1899. [Gyula Dávid finished secondary school in Debrecen. Then he studied in Utrecht. Zoványi, 135; Dávid G (1890) Református keresztyén hittan (based on extracts from Böhl's dogmatics). Budapest: Kókai, Lajos; Szögi's study does not mention Dávid's Utrecht studies. Zoványi, 135; neither Szögi 2000, nor Bozzay mention it.]

\section{Mutual Recommendations and Invitations to Disciples}

There were other forms of the professors' concern for the students. Students going on their study trips could receive letters of recommendation addressed to the professor of their destination university, as happened in the following case. Böhl indicated in May 1877 that he would be glad to receive József Erdős who was recommended by Balogh. [R 1516/24: 5 May 1877] At the beginning of the new semester Böhl wrote that their young friend Erdős had returned and started his studies with renewed energy. Böhl considered Erdős as a token of his affectionate friendship with Balogh. He also expressed his wish that Erdős should not be the last one whom Balogh sent to Vienna. [R 1516/24: 1 October 1878] Böhl himself declared that he really likes Hungarians and requires as many as them as possible to come. [R 1595/15: 29 October 1892]

Obviously, Böhl regarded promoting the further career of their students as his duty which he shared with Balogh. Besides the attention to their disciples, invitations often reoccur in Böhl's letters. In 1876 he wrote about four Hungarian Lutheran students who attended his lectures on Calvinist symbolics, about which he also complained: 'Calvinists do not come any more. Their absence is noticeable.' [R 1516/24: 31 July 1876] Böhl regarded supporting the Viennese studies of Hungarian students as very important. A decade later, in 1884 he encouraged Balogh to send him students, which he would not regret. [R 1516/24: 4 April 1884] The following year he inquired whether anybody was going to Vienna from Debrecen. [R 1516/24: 12 August 1885]

In 1886 he repeatedly asked Balogh to send students, as it was crucially necessary to send workers to the harvest. This is the evidence that he attempted to form Luther-spirited students from the ones he was responsible for. Erdős, Keck and Venetianer were such students, who worked unremittingly. In 1889 Böhl wrote about feeling orphaned as there were no Hungarian students in Vienna that year. [R 1516/24: 8 February 1889] In 1892 he asked repeatedly whether any Hungarians were coming to Vienna, since he would be happy to see a Hungarian among the students. [R 1595/15: 29 October 1892] It does not often occur that a professor himself tries to recruit students. 


\section{Students, Ministers, and Peregrines}

The lack of German language proficiency presented a serious problem. Students of theology knew very little German and only occasionally bought reference books. [HDC: 30 May 1885] This explains why Böhl asked Balogh to tell Erdős, who was going to Vienna, to learn German diligently. [R 1516/24: 11 June 1877] At the University of Utrecht, where Böhl sent his disciples, German was also necessary. Böhl asked one of his colleagues there to help Hungarian students to learn German, as it is advantageous to speak this language, and it also helps students to communicate with the professors. The statistics of the 1894/95 Debrecen academic bulletin refer to the weak language proficiency of Hungarian students, since out of 167 students, only 58 felt it necessary to study foreign languages, 20 studied English, 22 French, and another 16 German. The contemporary Lajos Csiky found that a decent number. The problem for him was that as a result of inconsistency this figure dropped by half in the second semester (Csiky 1895: 25). There were students in Vienna, such as Emil Kovács, who did not speak German, although he thought that he understood the lectures. [R 1595/15: 29 October 1892. Emil Kovács studied in Zurich and then later in Leipzig.] It is questionable if he understood them in any depth. A beautiful myth was destroyed by this experience since that a lot of students pretended to have excellent language proficiency during their studies abroad. Reality, however, as Böhl highlighted, was different. Lack of language proficiency proved to be a serious obstacle. The student could be talented, such as Ferenc Kiss, but at the beginning he knew too little German to communicate with Böhl. The professor acrimoniously remarked that 'these gentlemen might respect us by learning our beautiful language'. [R 1516/24: 25, January 1887] Böhl regretted that the language was such a hindering factor for some students. Linguistic deficiencies, however, could be made up for. István Orosz was exemplary from this aspect. He arrived with little German, yet later Böhl could write about him that he was an excellent student. [R 1516/24: Böhl's undated letter] Lack of language proficiency was general in the case of ministers, also. When in 1884 Balogh mentioned that a German book of theology should have been promoted, very few ministers had enough German and Greek, therefore they could not count on them to be interested in the volume. [HDC: 15 September 1884]

Apparently, the College of Debrecen did not only send excellent talents abroad, but also mediocre or weak students. On 28 September Balogh noted that a student called Lajos Takács would go to the Protestant Theological Institute of Vienna. He wrote that Takács was not outstanding, but he would like to extend his knowledge. He expressed his hope that Böhl would influence him and expresses his pleasure that another Hungarian student goes to the same institute in Vienna. [HDC: 28 September 1885] It is not clear, however, why Balogh decide to recommend Takács, having seen his modest 
abilities. He might have been motivated by his social sensitivity, the practical common sense of the student, or his spiritual or personal attitude. Böhl was not delighted seeing the performance of the student. Takács's previous qualifications were weak, weaker than those of other Hungarian students. Böhl thought that the knowledge of Greek, Latin and Hebrew could be found only in small measure in Balogh's compatriots. [R 1516/24: 7 June 1886] Even Balogh himself repeatedly admitted that "Takács, the theologian, is "poorly armed" for his studies in Vienna, but he had a strong wish to visit You in Vienna, and I do not want to discourage him.' [HDC: 1 February 1887] Regarding Takács, he mentioned having written to the student's father about trying to help him but, added and just between them, that students like him should have never been allowed to study at university, as he was completely incapable. [R 1516/24: 25 January 1887] He thought that Takács had no affinity to theology. He did not know what motivated such people to follow such demanding studies. [R 1516/24: 17 February 1887] It is interesting to note that among students who finished secondary school in Debrecen, it was Takács who spent the longest time in Vienna, between 5 October 1885 and 19 March 1888. [R 1516/24: 17 February 1887] [Lajos Takács was born in Berettyószéplak as the son of a Reformed minister. He finished secondary school in Debrecen. He enrolled in Vienna on 5 October 1885, then left on 19 March 1888. He also visited the university there, as in Patyi 2015: 594. Kálmán Rácz was registered in Zürich between 19 April 1893 and 27 July 1893, see Szögi 2000: 103]

\section{The Intellectual Background of the Students. Two Outstanding Students: József Erdős és Sándor Venetianer}

There are occasional references to the intellectual background of the students who studied in Vienna. Böhl judged Kálmán Rácz, who later became academic professor at Pápa (Zoványi 1977: 495), who was from Mád and had studied in Sárospatak, a rationalist, while he found Emil Kovács (Patyi 2015: 594), who had studied theology in Debrecen, positivist. Students encountered different intellectual streams abroad, which was not always positive. Those sent abroad did not always fulfil the hopes of Balogh. One such case was Gábor Jánosi, who studied in Vienna in 1874 and 1875, then in Edinburgh in 1875 and 1876, and whom Balogh recommended to the Scots, but who turned to modernism and rationalism. [HDC: 27 March 1876] Balogh thought that naturalistic rationalism spread to Hungary from Germany, while several evangelic flows came from Scotland to Hungary in that decade (Kovács 2006: 206-207; Kool 1995: 54). Böhl had a crucial role in the positive effects of revival and spiritual renewal that originated from abroad, as Balogh testified: 'he gives full courage and full faith to one or two students every year, for which special missionary work we are grateful.' [HDC: post 30 December 
1886, not dated] There are also examples of personal piety, such as Takács, who Balogh noted greatly approached God. [HDC: 30 December 1886] In the case of József Póth, he frequently mentions his religious devotion. [HDC: 7 June 1886, 7 September 1886] As it becomes apparent, Balogh sent students abroad after serious consideration, based on their studies, religious orientations, thorough academic experiencesof the international piety or spiritual impacts that were held valuable, and based on which of them would be best able to serve similarly as ministers at home after their return to Hungary. [Kálmán Rácz enrolled on 3 October 1892 and left in March 1893. He studied in Zurich in 1893. Patyi 2015: 594; Kálmán Rácz was registered in Zurich between 19 April 1893 and 27 July 1893. Szögi L (2015) Magyarországi diákok svájci és hollandiai egyetemeken 1789-1919. Budapest: Eötvös Loránd Tudományegyetem Levéltára. (henceforth = Szögi 2000: 103.] [Emil Kovács finished secondary school in Debrecen. He enrolled on 11 October 1892 and left in March 1893. He studied in 1893 in Zurich, then in 1895 in Leipzig; Szögi 2000: 103; Szögi 2001: 404. I have not found any further details about his life.] [Gábor Jánosi enrolled in Vienna on 1 October 1874 and left on 25 July 1875. Previously, in 1874 he also studied in Edinburgh. Patyi 2015: 588. However, Gabriella Sárközi has contradicting information, as she found that Jánosi enrolled in Edinburgh in 1875. She marks his Viennese year as 1874 with a question mark. Sárközi 2013: 123.]

Balogh kept in touch with his disciples abroad. Böhl reported to Balogh about József Erdős that his hopes were fulfilled, as Erdős is loyal and has a childlike spirit. [R 1516/24: 18 February 1878] In his answer Balogh wrote that the students showed a great progress in his studies and mentions his professor in Vienna with deserved respect. He hoped that Erdős will remain worthy of Böhl's trust in the future, and that he is going to be an excellent minister of his church. Finally, he asked Böhl to give Erdős his regards. [HDC: 7 October 1878]

Among the students József Erdős had the most successful professional career as Professor of Theology at the College of Debrecen. He was awarded his licentiate in April 1888 and doctorate in March 1891 by the Faculty of Theology in Vienna (Zoványi 1977: 179). The reason for Vienna was that before the Faculty of Theology of the Hungarian Royal University of Debrecen received the right to award the doctorate in 1914, Hungarian reformed theologians could only receive this degree inside the Austro-Hungarian Empire at the Institute in Vienna, which had previously been granted the right to grant doctor degrees as well as the right to and habilitate (Schwarz 2015: 28). Balogh informed Böhl on 21 April 1888 about the news that the day before the professors of the theology had been summoned to give their opinion about applications for the Department of the New Testament position. From the seven applicants the board recommended Erdős in first place and 
Venetianer in second place. Even though all the professors admitted that from the perspective of academic credentials first place should have gone to Venetianer their friend then serving in Rohrbach near Odessa in Russia, (Zoványi 1977: 683) but Erdős was better-known in Debrecen. They shared the opinion that Venetianer had a difficult personality, and consequently Erdős could fill the position. This was the first instance when one of Böhl's 'disciples' obtained a position in a department in Debrecen [HDC: 21 April 1888] wrote Balogh modestly, not mentioning that Erdős was also his student. It was the second application by Venetianer to Debrecen. First, in 1887, he applied to the Department of the Old Testament then withdrew from it. The second time, in 1888, he applied for the position at the Department of the New Testament, but as already mentioned, this position went to Erdős, with whom, by the way, they were friends (Kocsis 1988: 247; Kövér 2012: 10; Schwarz 2019: 189-190). [Venetianer served as a minister between 1887 and 1889 in Russia, in Rohrbach near Odessa.]

Böhl also aimed to help other students to positions. On 17 July 1883 he wrote that he would like Zsigmond Keck to be employed by the Transtibiscan Church District, similarly to what happened to Erdős, Szalay, Venetianer, or earlier to Károly Rácz. [R 1516/24: 17 July 1883] Böhl really wanted to find a position for Keck in Budapest. [R 1516/24: 22 January 1889] He did not exclude careers other than that of minister. He regarded Keck as better suited to be an academic than a minister. [R 1516/24: 25 January 1887] He noted that it would be more useful to give Venetianer, Keck and Erdős academic positions rather than the translation of his dogmatics, as the living word is worth more than printed letters. [R 1516/24: 17 February 1887] His ambition was successful only in Erdős's case.

\section{Böhl's Dogmatics as the Theological Foundation of Orthodox Revivalism}

From the aspect of apologetics, both professors considered important not only the propagation of articles, news and essays in periodicals, but also academic works mediating deep theological insight. Consequently, the Hungarian translation of Böhl's 1887 dogmatics (Böhl 1887) appeared in the letters. It was not by chance that the first names mentioned were from the Kohlbrügge-circle. Károly Rácz emerged first as a translator, but Balogh did not consider his Hungarian style appropriate. He recommended another disciple, József Erdős instead. He suggested that the translations should be introduced by a renowned Hungarian theologian, such as Imre Révész, the already mentioned minister from Debrecen (Zoványi 1977: 506-507), who would outline the importance of the translation in a few sentences, also giving weight to the work for Hungarian readers. Erdős, being still a young man, did not have enough credit with Hungarian clerics. Eventually Böhl's complete dogmatics was not translated into Hungarian, but parts of it were 
published in Hungarian. Balogh noted that he read the excerpt from the dogmatics titled 'About the visible Church' in Erdôs's translation in the periodical Szabad Egyház (Free Church). He found the translation well-done, understandable and clear enough. [HDC: 30 December 1886] It must be underlined that it might have been a trial translation and it is probable that Böhl may have published parts of it before 1887 . Another name emerged later, that of János Kovács (Patyi 2015: 593), who organised and established congregations in America, who could have translated for Böhl. In any case he was talented enough, he could start translating the dogmatics, even though Böhl could not judge whether he was able to do it or not. He asked for Balogh's opinion. [R 1516/24: Vienna, 24 January 1891]

A few years later, on 27 December 1890, Balogh noted that Böhl's short dogmatics had been published in Hungarian, translated from the Dutch by Gyula Dávid (Patyi 2015: 593). At Balogh's request, József Erdős praised it in the Debreceni Protestáns Lap [DPL 1890. 464-465. The journal covers the topic in this year's issues too: 111-112, 174-175, 267, 457], and Venetianer in the Szabad Egyház. [HDC: 27 December 1890] Andor Hamar's book review in the Protestáns Egyház és Iskolai Lap (Protestant Church and School Review) thoroughly criticised the job done by the translator, rather than the dogmatics (Hamar 1891: 116-118). The translation of Böhl's dogmatics was still on the agenda, which was also justified by the linguistically unsuccessful Hungarian version based upon the abridged Dutch edition. Balogh kept thinking that Erdős would have been the most suitable person for the translation. [HDC: 23 December 1891] As far as I know, the expected translation still has not materialised even today. [(7 October 1885; 24 July 1886) He finished secondary school in Debrecen. Then he studied in Utrechtben in 1886. Zoványi, 135; Dávid G (1890) Református keresztyén hittan (Böhl dogmatikájának holland kivonata alapján). Budapest: Kókai, Lajos; Szögi’s related work does not mention Gyula Dávid's Utrecht studies. Zoványi, 135; neither Szögi 2000, nor Bozzay mention him.]

\section{The Role of Periodicals Based on the Correspondence}

Similar to literary works, studies in theology were also published in contemporary periodicals in the 19th century serially or in excerpts. As shown in the previous chapter, an excerpt from Böhl's dogmatics appeared in the Szabad Egyház. By that time newspapers had important roles in shaping public opinion, which was also experienced by the students who visited Vienna. As shown before, Eduard Böhl himself redacted a journal, besides writing for a great number of different newspapers.

Both professors wrote articles for the Szabad Egyház (Zoványi 1977: 561), having started in 1884 and redacted by one of Böhl's first students, Károly Rácz. Balogh noted that there is still a need for competent authors in this 
journal. [HDC: 30 March 1885] Böhl was pleased hearing that Balogh so nicely supported Károly Rácz, but he found one of the issues very monotonous, as nearly all the articles were written by Rácz. [R 1595/15: 19 October 1892]

According to Balogh, other problems emerged concerning the journal: 'I mark that my protegee, [Ferenc] Kecskeméti, the minister of Békés, a leading contributor to Szabad Egyház, deeply denigrated the journal, chiefly with his vitriolic articles and letters. He ignited the anger of nearly all the Protestant journals and theological professors in Hungary. The Szabad Egyház is going to remain the journal for simple people as the higher class does not take cognizance of it. Orthodoxy cannot neglect the literate class. It cannot afford to be narrow-minded. The duty of orthodoxy is not to imitate stoic pride.' [R 1516/24: 24 January 1891] Balogh was reasonably afraid that their narrowmindedness sheds a bad light on the movement. Even though Balogh shared the same platform as Kecskeméti, even he found Kecskeméti's style too much.

Apparently, the platform of new orthodoxy was far from homogeneous, even among the adherents there were differences between their views. It was Ferenc Kecskeméti and József Szalay, who urged the increase in the number of issues-a request Rácz refused. Then József Szalay launched his own journal, the Keresztyén (Christian) (Zoványi 1977: 567; Csohány 1987: 172) Kecskeméti started his own journal in 1895, Evangélista (The Evangelist) (Csohány 1987: 166). The two were united from 1900 as the Keresztyén Evangélista (The Christian Evangelist) (Zoványi 1977: 301). Certain revivalist centres founded their own journals, which did not help the activity of the Szabad Egyház (Csohány 1987: 167).

One of the main reasons for the conflict were the different opinions articulated about how the state and church should relate to one another. [Ferenc Kecskeméty spent two years in Edinburgh from 1878. Between 1881 and in 1884 he partly studied, partly served as minister in North America. He became a minister in Békés from 1885, and member of parliament between 1901 and 1910. Zoványi, 301; Sárközi, 123; Kool, 51. Here the name appears in another version, as Kecskeméthy. Jenő Szigeti wrote that Szalay too was minister in Békés, based on A békési paraszt-ecclesiolák válsága és a baptista gyülekezet megalakulása (1890-1891). In (1986) Mert ezt Isten hagyta... Tanulmányok a népi vallásosság köréből). Budapest: Magvető.] [Szalai was born in Makó, in the same place and year as Kecskeméti, in 1855. He finished his theological studies in Budapest simultaneously with Kecskeméti. They studied in Edinburgh together from 1878, then he spent the spring semester of 1880 in Vienna. Zoványi, 567; Sárközi defines the period in Vienna as between Spring 1880 and Spring 1881, 124. Interestingly, Patyi only mentions another József Szalay from the year 1888, 378.] 


\section{Three Students' Short Visit to Vienna}

Vienna was not simply a place to study for Hungarian students who travelled abroad but was also a place-the 'Kaiserstadt' - to stop on their way to Western Europe. In a letter dated 28 April 1877 Balogh recommended to Böhl's goodwill a student who wanted to make an introductory visit to Böhl on his way to Edinburgh, but whose name has become illegible on the damaged document. [HDC: 28 April 1877] We know that some students on stipend in Germany also got in touch with the professor in Vienna. We do not know, however, how long they spent in the imperial city. From the correspondence we have information about two students who spent some time in Vienna, one was József Dicsőfi (Zoványi 1977: 150), later Professor of Theology in Debrecen, and Kálmán Révész (Zoványi 1977: 509), later Bishop of the Cistibiscan Church District. Dicsőfi's father mentioned that his son wrote him about the warm welcome he received in Vienna. [HDC: 15 September 1884]

In relation to Kálmán Révész, Balogh wrote a letter of recommendation on 16 December 1885, in which he described the student as 'the son of our fiery author, Imre Révész', who finished his studies in the College of Debrecen where he achieved the office of 'senior', and then studied at the University of Berlin. Balogh asked Böhl to welcome him with special attention which he deserved by his talent and discipline, but also out of regard for his renowned father. He described the student as being especially interested in historical and palaeographical researche besides being a reformed theologian. [HDC: 16 September 1885] In his case Balogh recommended a friend's son, who, however, did not spend a long time in Vienna, but found it important to stop there. [József Dicsőfi studied in Leipzig (15 October 1883 to 12 February 1884) and in Marburg (from 5 May 1884 to an unknown date). Szögi 2001: 398, 433] [Kálmán Révész was a student at the University of Berlin between 20 October 1885 and 7 August 1886. Szögi 2001: 107]

\section{Böhl's Protégée's in Debrecen}

Caring for students, paving their way beyond the institution was important for both professors. The patronised students whom Böhl sent to Debrecen were characteristically upper-year students and some of them came to Debrecen only for their minister's examinations, while others attended ordinary lessons. On 26 April 1883 Böhl reports on a German Lutheran theologian from Styria called Royer, who converted to Calvinism. The question was whether Royer could find a job in Hungary, where there are seven or eight German-language reformed congregations. Böhl wished to know if it was necessary for his protégée to take the minister's examinations administered by Balogh's college. He also asked if Royer could take the faculty exam in Vienna and then take only the second one in front of the superintendent in Debrecen. Böhl was expecting Balogh's detailed answer, adding that 
Hungary could greatly profit from such a person. [R 1516/24: 26 April 1883] As mentioned earlier, Böhl also recommended Zsigmond Keck, of whose diligence not only he but also his colleagues were convinced. [R 1516/24: 4 April 1884] Bálint Révész (Zoványi 1977: 506), the Transtibiscan bishop expressed that he knew all of Böhl's disciples in Debrecen and appreciated them. [HDC: 15 September 1884] This appreciation suggests that the close relationship of the two professors was well-known among the leading churchmen. [There are two brothers among those who converted from Lutheranism to Calvinism, Moritz August Royer and Karl Royer. So far it has not been possible to clarify to whom Böhl wrote about. Schwarz, 236; M. A. Royer's letters to Böhl between 1884 and 1897 can be found in Amsterdam. Geppert, Kerstin (18361904) Inventar des Archivs von Prof. Dr. Eduard Böhl, 18. More details on https://www.hdc.vu.nl/nl/Images/108_Eduard_Boehl_tcm215-773569.pdf]

Not all students came up to the expectations, however. Among Böhl's disciples in Vienna, József Papy was by far the best, as he first acquired the German language, then studied other subjects, promising a great career. [R 1516/24: 4 April 1884] On 19 November 1884 Böhl described him as the student who was using his commentaries dutifully and was going to take his final exam in Debrecen in April 1885. [R 1516/24: 19 November 1884] But after that good start Papy's theologian's career came to a dead end. On 7 June 1886, Böhl regretfully wrote to Balogh that Papy gave up his studies for no known reason. [R 1516/24: 7 June 1886] This information is affirmed by József Szinnyei's biography, which tells us that the ex-minister ran his own farm (Szinnyei 1905: 391-392) and later, between 1910 and 1912 became the Reformed Chief Curator and in 1901 was a candidate for the parliament. [József Papy, having been born in Hódmezővásárhely, graduated in theology in Debrecen. He studied in Vienna between 2 October 1882 and 14 July 1884. Patyi 2015: 593.]

\section{Reformed, Jewish and Catholic Students at the Protestant Theological Institute of Vienna between 1864 and 1899}

During Böhl's Vienna years, between 1864 and 1899, 304 Hungarian students enrolled to the Protestant Theological Institute in Vienna. Among them there were 48 Reformed Protestant, two Jewish and one Catholic. In the correspondence available 16 names are mentioned. We cannot say that Hungarian Reformed students would have been present in Vienna in a great number, since even the professors kept only a few students in minds. More than half of the students (30 people) studied in Debrecen in secondary school (26) or theological education (4). Out of those 16 are mentioned in the letters. However, out of the 67 Hungarian students enrolling between 1900 and 1918, we know of only four Reformed students of whom only one finished theology in Debrecen. Based on these figures we may presume that the 
personal relationship between Böhl and Balogh turned the attention of many towards the imperial city. It seems likely that József Erdős did not encourage his students' study trips to Vienna. Böhl's successor, Carl Alphons Witz-Oberlin (1845-1818) did not have such a close relationship with Debrecen as his predecessor.

\section{Concluding Thoughts}

Both Ferenc Balogh and Eduard Böhl played an important role in the lives of their institutions and their Church. Their correspondence, of which an important topic was the life of their disciples, lasted from 1867 till Böhl's death in 1903. The fact that they both represented the same intellectual stream greatly facilitated their relationship. Vienna became the destination of the Western European peregrination of the Hungarian Reformed students in their period, thanks to the personal contact of the two professors. Balogh oriented many of his students to the 'Kaiserstadt', and then Böhl helped them with his thorough attention. There were also students, right before finishing their studies, whom Böhl suggested to become professors in Debrecen. Several talented disciples of Balogh and Böhl played important roles in the Hungarian Reformed Church. Out of these people I would highlight Károly Rácz, Sándor Venetianer, and József Erdős. The latter also become Balogh's colleague in Debrecen. Besides their correspondence and personal meetings, the professors could occasionally find other channels to receive information about each other. The preparedness of the students sent to Vienna was diverse. Lajos Takács exemplifies one extreme who, despite not proving to be talented, spent two and a half years in the institute. The students' German linguistic deficiencies are also often mentioned. There were some who could make up for their drawbacks, such as István Orosz, [Böhl's undated letter] or Ferenc Kiss (Zoványi 1977: 318 ; Patyi 2015: 594), later Professor of Theology in Debrecen, the first Rector of the University of Debrecen, who was personally encouraged by Balogh to go to Vienna, where he enrolled on 6 October 1886 and graduated on 6 July 1887. Ferenc Balogh even asked his colleague how he found this student. Although he thought the student had a lot more to learn in Vienna than in Debrecen, he hoped that the young man would develop in the right order. [R 1516/24: 30 December 1886] Böhl answered Balogh's question on 25 January 1887 that Kiss seemed to be talented but knows too little German to contact him. 'These gentlemen should do the courtesy towards us to learn our beautiful language.' [R 1516/24: 25 December 1887] This remark is even more interesting because, according to Patyi, Ferenc Kiss had also studied in the German-language Käsmark/Kežmarok (Patyi 2015: 594) before, and therefore the remark on his German proficiency is thought-provoking. Later, however, Balogh's opinion of Kiss proved true, as Kiss became an outstanding personage of the Hungarian Church. 
The correspondence demonstrates that the professors did not limit their attentions to the university years, but also followed their disciples' later career. They heartily cared for them in terms of helping them obtain a good minister's or professor's position. The importance of personal relationships is apparent from the fact that after Eduard Böhl's and later Ferenc Balogh's death the number of scholarship students dramatically decreased.

\section{Appendix: Reformed, Jewish and Catholic Students at the Protestant The- ological Institute in Vienna between 1864 and 1899}

*Sources of the chart: Patyi 2015, Szögi 2003. Names are given in the form, which are in the matriculations. In bold are mentioned in the letters.

\begin{tabular}{|c|c|c|c|c|c|}
\hline Name & Enrolment & Leaving & Devotion & $\begin{array}{l}\text { Relationship to } \\
\text { Debrecen }\end{array}$ & $\begin{array}{l}\text { Further } \\
\text { Studies }\end{array}$ \\
\hline Fehér, Joseph & 1864. 10. 8. & 1865. 7.31. & ref. & no & \\
\hline Trokan, Alexander & 1864.4.5. & 1866. 7. 16. & ref. & no & \\
\hline Rácz, Carl & 1866. 10. 6. & 1867. 7. 28. & ref. & secondary school & \\
\hline Poór, Joseph & 1867. 10. 8. & 1868. 7. 17. & ref. & no & \\
\hline Mihályi, Karl & 1869. 10. 14. & 1870. 7. 18. & ref. & no & \\
\hline Nagy, Alexius & 1869. 10. 1. & 1870.4 .1$. & ref. & secondary school & $\begin{array}{l}\text { Berlin 1870, } \\
\text { Utrecht } \\
1870\end{array}$ \\
\hline $\begin{array}{l}\text { Németh /Dalotti/, } \\
\text { Edmund /Ödön, } \\
\text { Győző }\end{array}$ & 1869.10 .5$. & 1870.7. 25. & ref. & no & \\
\hline Félegyházi, Anton & 1870.10 .11$. & 1871. 2. 28. & ref. & secondary school & \\
\hline Görög, Karl & 1870.3. 18. & 1871.10 .1$. & ref. & no & \\
\hline Kalas, Stephan & 1870.10 .31$. & 1871.2. 28. & ref. & secondary school & \\
\hline Mészöly, Caspar & 1870.10 .15$. & 1871. 2. 28. & ref. & secondary school & $\begin{array}{l}\text { Zurich 1871, } \\
\text { Heidelberg } \\
1871 \\
\end{array}$ \\
\hline Nagy, Joseph & 1870.11 .18$. & 1871. 10. 1. & ref. & no & \\
\hline Rácz, Johann & 1870.10 .18$. & 1871. 2. 28. & ref. & secondary school & \\
\hline Szabó, Joseph & 1870. 10. 24. & 1871.7 .15$. & ref. & secondary school & \\
\hline Deák, Michael & 1871.5. 10. & 1872. 7. 27. & ref. & no & $\begin{array}{l}\text { Vienna TH } \\
1870, \\
\text { Utrecht } \\
1872 \\
\end{array}$ \\
\hline Simon, Alexius & 1871.5 .1 & 1871.7 .15$. & ref. & secondary school & \\
\hline Pápay, Paul & 1872. 10. 4. & 1872. 12. 7. & ref. & th. & \\
\hline Vityi, Bartholomeus & 1872. 4. 29. & 1872. 7. 15 . & ref. & secondary school & \\
\hline
\end{tabular}




\begin{tabular}{|c|c|c|c|c|c|}
\hline $\begin{array}{l}\text { Venetianer /Venezi- } \\
\text { aner/, Alexander } \\
\text { /Alexander Carl } \\
\text { Theodor/ }\end{array}$ & 1873. 10.3. & 1874. 4. 13. & israelite & no & $\begin{array}{l}\text { Vienna } \\
1871 \text {, Basel } \\
1874\end{array}$ \\
\hline Jánosi, Gabriel & 1874.10. 1. & 1875. 7. 21. & ref. & th. & $\begin{array}{l}\text { Edinburgh } \\
1874\end{array}$ \\
\hline Mozes, Andreas & 1874. 10. 6. & 1875. 7. 21. & ref. & secondary school & \\
\hline Oláh, Alexander & 1876.10 .16$. & 1876. 12. 16. & ref. & secondary school & \\
\hline $\begin{array}{l}\text { Sarkadi /Sarkady/, } \\
\text { Titus }\end{array}$ & 1876. 12. 5. & 1877.2. 6. & ref. & no & \\
\hline Berde, Alexander & 1877.10 .11 & 1878. 7. 20. & ref. & no & $\begin{array}{l}\text { Jena } 1881, \\
\text { Basel } 1882\end{array}$ \\
\hline Erdős, Joseph & 1877. 10. 2. & 1879. 7. 17. & ref. & secondary school & \\
\hline Orosz, Stephan & 1877. 10. 2. & 1878. 7. 20. & ref. & secondary school & $\begin{array}{l}\text { Vienna TH } \\
1877\end{array}$ \\
\hline $\begin{array}{l}\text { Szathmári } \\
\text { /Szathmáry/, Alex- } \\
\text { ander }\end{array}$ & 1877. 10. 23. & 1879.5 .7$. & ref. & secondary school & \\
\hline Tollas, Joseph & 1878.10 .17$. & 1879.7. 7. & ref. & no & \\
\hline Hajdú, Sigmund & 1879.10 .10$. & 1880.7 .15$. & ref. & secondary school & \\
\hline Puasztler, Moritz & $1879 \mathrm{~W}$ & & israelite & no & \\
\hline Keck, Sigmund & 1880. 10. 5. & 1883. 7. 16. & ref. & no & $\begin{array}{l}\text { Utrecht } \\
1885\end{array}$ \\
\hline Papy, Joseph & 1882. 10. 2. & 1884. 7. 14. & ref. & th. & \\
\hline $\begin{array}{l}\text { Ferenczy /Ferenczi/, } \\
\text { Julius }\end{array}$ & 1883. 11. 28. & 1884. 4. 8. & ref. & secondary school & $\begin{array}{l}\text { Vienna } \\
\text { 1886, Leip- } \\
\text { zig } 1887 \text {, } \\
\text { Berlin } 1888\end{array}$ \\
\hline Polgár, Samuel & 1883.10. 1. & 1884. 2. 4 . & ref. & no & \\
\hline $\begin{array}{l}\text { Seregély, Desider } \\
\text { /Desiderius/ }\end{array}$ & 1883.10. 1. & 1884. 4. 2. & ref. & no & \\
\hline Kovács, Johann 3 & 1884. 10. 6. & 1885.3.6. & ref. & secondary school & \\
\hline Póth, Joseph & 1884. 10. 2. & 1885.7. 11. & ref. & no & \\
\hline David, Julius & 1885. 10. 7. & 1886. 7. 24. & ref. & secondary school & $\begin{array}{l}\text { Utrecht } \\
1886\end{array}$ \\
\hline Takács, Ludwig & 1885.10 .5$. & 1888. 3. 19. & ref. & secondary school & Vienna 1886 \\
\hline Kiss, Franz & 1886. 10. 6. & 1887.7 .6$. & ref. & secondary school & \\
\hline Bereczk, Alexander & 1887.10 .15$. & $\begin{array}{l}\text { 1887. 3. } 15 . \\
\text { (sic!) }\end{array}$ & ref. & secondary school & \\
\hline Fogarasi, Valentin & 1887.10 .15$. & 1888. 7. 14. & ref. & secondary school & $\begin{array}{l}\text { Utrecht } \\
1888 \\
\end{array}$ \\
\hline Erfurth, Alexander & 1891.10 .12$. & 1893. 2. 26. & catholic & no & \\
\hline Kovács, Emil & 1892.10 .11$. & 1893.3.S & ref. & secondary school & $\begin{array}{l}\text { Zurich 1893, } \\
\text { Leipzig } \\
1895\end{array}$ \\
\hline
\end{tabular}




\begin{tabular}{|c|c|c|c|c|c|}
\hline Rácz, Koloman & 1892. 10. 3. & 1893.3.S & ref. & no & Zurich 1893 \\
\hline Gergely, Anton & 1894.10.31. & 1895.3. & ref. & no & \\
\hline Biberauer, Richard & 1895. 4. 25. & 1895.7 .11$. & ref. & no & $\begin{array}{l}\text { Budapest } \\
\text { Th., Berlin } \\
\text { 1894, Edin- } \\
\text { burgh } 1897\end{array}$ \\
\hline Lencz, Géza /Geiza/ & 1895.10 .4$. & 1896. 7. 15. & ref. & secondary school & \begin{tabular}{|l} 
Utrecht \\
1896 \\
\end{tabular} \\
\hline Juhász, Ladislaus & 1896.10 .1$. & 1898. 7. 9. & ref. & secondary school & $\begin{array}{l}\text { Budapest, } \\
\text { Sárospatak } \\
\text { Th, Lon- } \\
\text { don? } 1894 \\
\text { Utrecht } \\
\text { 1897, Berlin } \\
1901\end{array}$ \\
\hline Losonczi, Andreas & 1896. 10.8. & 1897. 7. 9. & ref. & secondary school & \\
\hline Kiss, Anton & 1897.10 .7$. & 1898. 1. 25. & ref. & no & \\
\hline $\begin{array}{l}\text { Csomasz, Desider } \\
\text { /Desiderius/ }\end{array}$ & 1898. 10. 6. & 1899.7. 8. & ref. & no & \\
\hline
\end{tabular}

\section{Bibliography}

Böhl E (1887) Dogmatik. Darstellung der christlichen Glaubenslehre auf reformirtkirchlicher Grundlage. Amsterdam: Verl. v. Scheffer; Leipzig: R. Giegler; Basel: F. Schneider.

Csiky L (1895) (ed) A Debreczeni ev. Ref. Főiskola értesitôi az 1894-95. iskolai évröl. Debreczen: Városi Nyomda.

Csohány JA (1988) korszakváltások évszázada (1849-1950) A Debreceni Református Kollégium története szerk. Barcza József. Budapest: Zsinati Iroda, 192-300.

Csohány J (1987) Rácz Károly (1842-1925) lelkipásztor élete és munkássága.

In Csohány J: Tanulmányok Debrecen és a reformátusság múltjáról. I. kötet, pp. 162-174.

Csohány J (2011) Simai Erdős József. Egyháztörténeti Szemle 12(3) 68-76.

Czeglédy S (1988) A teológiai tanítása a Kollégiumban. A Debreceni Református Kollégium története szerk. Barcza József, Budapest: Zsinati Iroda.

*** (1903) Debreceni Protestáns Lap. 7 February. 6: 94-95.

Geppert K (2008) Inventar des Archivs von Prof. Dr. Eduard Böhl (1836-1903) 5.

https://www.hdc.vu.nl/nl/Images/108_Eduard_Boehl_tcm215-773569.pdf.

Forster RVT (2009) Eduard Böhl's (1836-1903) Concept for a Re-emergence of Reformation Thought. Frankfurt am Main: Peter Lang.

Hamar A (1891) PEIL 4: 116-118. 
Heil U and Schellenberg A (2016) (eds) Frömmigkeit: Historische, systematische, praktische Perspektiven Wiener Jahrbuch für Theologie, volume 11. Vienna: V\&R Unipress, Vienna University Press.

Kocsis E and Barcza J (1988) (eds) A Debreceni Református Kollégium története. Budapest: MREZS Irodájának Sajtóosztálya.

Kool AM (1995) Az Úr csodásan müködik, volume 1. Budapest: Harmat PMTI.

Kósa L (2001) Az elberfeld-debreceni diákcsere. A magyar református egyház és a német hitvalló egyház kapcsolatának egy fejezete. Protestáns Szemle 2-3: 104-142.

Kovács Á (2006) The History of the Free Church of Scotland's mission to the Jews in Budapest and its Impact on the Reformed Church of Hungary 1841-1914. Frankfurt am Main: Peter Lang.

Kovács T (2017) Die Allierten: Der österreichische reformierte Pietismus begegnet der ungarischen Neoorthodoxie. In Lášek JB and Kónya P (eds) Reformation in Mitteleuropa. Beiträge zur Reformationsgeschichte in den Ländern der Donaumonarchie. Prag-Prešov: Universitat.

Kövér A (2012) A Venetianer fivérek „förabbi, református lelkész és katolikus pap” Egy Morvaországból származó, Magyarországon élö zsidó család története a 19. sz. második felében. 10. http://www.izrael-immanuel.net/?p=3557 (downloaded on 19 March 2019).

Patyi G (2004) Magyarországi diákok bécsi egyetemeken és föiskolákon 1890-1918. Budapest: Eötvös Loránd Tudományegyetem Levéltára.

Patyi G, Simon Zs, Szabó M, Szögi L, Varga J (2015) Magyarországi diákok bécsi egyetemeken és föiskolákon 1867-1890. Budapest: Eötvös Loránd Tudományegyetem Levéltára.

Schwarz KW (2018) Academic relations between Debrecen and Vienna-exemplified by Eduard Böhl and Sándor Venetianer. Lecture at the Symposium at the Partium Christian University in Oradea / Nagyvárad / Großwardein, 23 November.

Schwarz KW (2015) Debrecen-Wien: Von István Szoboszlai Pap bis Zsigmond Varga. Studia Debreceni Teológiai Tanulmányok 7(2): 28.

Schwarz KW (2019) [E]minently qualified for a theological professorship«. Der Absolvent der Wiener Fakultät Alexander Venetianer und seine fehlgeschlagene akademischen Ambitionen. In Heil U, Klein A, Schellenberg A (eds) Autor und Autorität. Historische, systematische und praktische Perspektiven Wiener Jahrbuch für Theologie, Band 12. Vienna: V\&R Unipress, Vienna University Press, pp. 181-194.

Szász L (2017) A Bécsi Protestáns Teológiai Intézet magyar református hallgatói (1821-1918). In Sasfi Cs and Ugrai J (eds) Iskola, müvelödés, társadalom. Az oktatás, nevelés és müvelödés társadalomtörténetei látószögei. Budapest: Hajnal István Kör -Társadalomtörténeti, pp. 175-187.

Szinnyei J (1905) Magyar írók élete és munkái. Budapest: Hornyászky, volume 10, pp. 391-392. 
Szinnyei J (1906) Magyar írók élete és munkái. Budapest: Hornyászky, volume XI, pp. 315-318.

Szögi L and Kiss JM (2003) Magyarországi diákok bécsi egyetemeken és fóiskolákon 1849-1867. Budapest: Eötvös Loránd Tudományegyetem Levéltára.

Zoványi J (1977) Egyháztörténeti lexikon. Budapest: MREZS Sajtóosztálya.

HDC: post 30 December 1886

R 1516/24: 17 July 1883

\section{Online content}

http://www.macse.org/gudenus/mcsat/fam.aspx?id=95663_[downloaded: 2 January 2019]

https://hu.wikibooks.org/wiki/C\%C3\%ADmerhat\%C3\%A1roz\%C3\%B3/Papy_c\%C3\%ADmer [downloaded: 7 January 2019]. 